\title{
Effect of Au Precursor and Support on the Catalytic Activity of the Nano-Au-Catalysts for Propane Complete Oxidation
}

\author{
Arshid M. Ali, ${ }^{1}$ Muhammad A. Daous, ${ }^{1}$ Ahmed Arafat, ${ }^{1}$ Abdulraheem A. AlZahrani, ${ }^{1}$ Yahia \\ Alhamed, ${ }^{1}$ Turdimuhammad Abdullah, ${ }^{1}$ and Lachezar A. Petrov ${ }^{2}$ \\ ${ }^{1}$ Department of Chemical and Materials Engineering, Faculty of Engineering, King Abdulaziz University, Jeddah 21589, Saudi Arabia \\ ${ }^{2}$ SABIC Chair of Catalysis, King Abdulaziz University, Jeddah 21589, Saudi Arabia
}

Correspondence should be addressed to Arshid M. Ali; amsali@kau.edu.sa

Received 26 May 2015; Revised 1 November 2015; Accepted 4 November 2015

Academic Editor: Sherine Obare

Copyright (C) 2015 Arshid M. Ali et al. This is an open access article distributed under the Creative Commons Attribution License, which permits unrestricted use, distribution, and reproduction in any medium, provided the original work is properly cited.

Catalytic activity of nano-Au-catalyst(s) for the complete propane oxidation was investigated. The results showed that the nature of both $\mathrm{Au}$ precursor and support strongly influences catalytic activity of the Au-catalyst(s) for the propane oxidation. Oxidation state, size, and dispersion of Au nanoparticles in the Au-catalysts, surface area, crystallinity, phase structure, and redox property

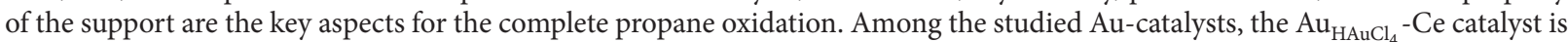
found to be the most active catalyst.

\section{Introduction}

VOCs are a wide range of chemical compounds emitted from both chemical and petrochemical process industries [1-3]. According to US Environmental Protection Agency (EPA), more than 300 chemical compounds are VOCs [1]. Most of the VOCs exhibited similar behavior in the atmosphere in spite of the fact that both physical and chemical properties of these compounds are very different from each other [4]. Emission of VOCs into atmosphere causes serious air pollution and environmental issues such as stratospheric ozone depletion, formation of ground level ozone, photochemical smog, and aggravation of the global greenhouse effect [47]. Henceforth, low cost, effective, and efficient reduction of VOCs is still one of the main challenges in chemical and industrial processes [1].

Among the applied methods, catalytic oxidation is so far the most efficient method for the abatement of VOCs at low cost [8]. This method is not limited by concentration, even very low concentrated VOCs $(<1 \%)$ could be eliminated [2]. Also, catalytic oxidation requires much lower temperature than the conventional thermal incineration. Additionally, instead of transferring the pollutant compounds to another phase, complete oxidation of VOC could be achieved by using catalytic oxidation processes [9].

Platinum and palladium catalysts were widely used for the oxidation of VOCs [9-11]. Recent studies showed that because of higher activity, better selectivity, and comparatively lower cost as to that of platinum and palladium, the Au-catalysts are expected to have practical application for the removal of VOCs $[12,13]$.

The catalytic performance of the Au containing catalysts depends on the size of the gold, its oxidation state, physical and chemical properties of the support [14-18], and surface morphology.

Many studies [19-23] had shown that Au-catalysts properties are very sensitive to the catalyst preparation protocols such as $\mathrm{pH}$ of the liquid media [24-27], temperature of precipitation of gold, used precipitating agent [28-30], and calcination temperature $[14,31-34]$.

Usually, in the preparation of Au-catalysts, chloroauric acid is used as Au precursor. Several other Au precursors, such as $\mathrm{Au}\left(\mathrm{PPh}_{3}\right)(\mathrm{NO})_{3}$ and $\mathrm{Au}$ acetate, were also used for the preparation of Au-catalysts [35-37]. However, until now, the aspects of the influence of Au precursors on the catalytic activity of Au-catalysts have not been studied systematically. 
TABLE 1: Summary of the prepared catalysts.

\begin{tabular}{|c|c|c|}
\hline Composition & Precursor & Nomenclature \\
\hline $1 \% \mathrm{Au}-\mathrm{CeO}_{2}$ & Chloroauric acid trihydrate & $\mathrm{Au}_{\mathrm{HAuCl}_{4}}-\mathrm{Ce}$ \\
\hline $1 \% \mathrm{Au}-\mathrm{ZrO} \mathrm{Z}_{2}$ & Chloroauric acid trihydrate & $\mathrm{Au}_{\mathrm{HAuCl}_{4}}-\mathrm{Zr}$ \\
\hline $1 \% \mathrm{Au}-75 \% \mathrm{CeO}_{2}-25 \% \mathrm{ZrO}_{2}$ & Chloroauric acid trihydrate & $\mathrm{Au}_{\mathrm{HAuCl}_{4}}-\mathrm{Ce}-\mathrm{Zr}$ \\
\hline $1 \% \mathrm{Au}-\mathrm{CeO}_{2}$ & Gold (III) bromide & $\mathrm{Au}_{\mathrm{AuBr}_{3}}-\mathrm{Ce}$ \\
\hline $1 \% \mathrm{Au}-\mathrm{CeO}_{2}$ & Gold monoiodide & $\mathrm{Au}_{\mathrm{AuI}}-\mathrm{Ce}$ \\
\hline
\end{tabular}

None of the published studies is yet reported on the effect of $\mathrm{Au}$ precursor on the catalytic activity of the Au-catalysts for the complete oxidation of propane.

At this moment there is no clear understanding regarding which oxidation state of $\mathrm{Au}$ atoms (either $\mathrm{Au}^{+1}$ or $\mathrm{Au}^{+3}$ ) is more active in the reactions by using gold catalysts [34, 3841]. Based on the available literature, it is estimated that based on different $\mathrm{Au}$ valence states in the different Au precursors, the Au oxidation state in different catalyst will differ and we might be able to prepare catalyst with beforehand defined properties.

In this study, effect of $\mathrm{CeO}_{2}$ and $\mathrm{ZrO}_{2}$ supports and different $\mathrm{Au}$ halogen containing precursors, such as $\mathrm{HAuCl}_{4} \cdot 3 \mathrm{H}_{2} \mathrm{O}$, $\mathrm{AuBr}_{3}$, and AuI, on the catalytic activity of Au-catalysts for the complete oxidation of propane is investigated and were characterized by using a wide range of analytical techniques, such as XRD, XPS, TEM, TPR, and BET.

\section{Experimental}

2.1. Materials. The following chemical materials were used for the preparation of the Au-catalyst (as summarized in Table 1): potassium hydroxide $(\mathrm{KOH})$ 86\%, Fluka; nitric acid $\left(\mathrm{HNO}_{3}\right)$ 69\%, UN 2013; magnesium citrate $\left(\mathrm{C}_{12} \mathrm{H}_{10} \mathrm{Mg}_{3} \mathrm{O}_{14} \cdot 9 \mathrm{H}_{2} \mathrm{O}\right)$ 95\%, Fluka; cerium oxide $\left(\mathrm{CeO}_{2}\right)$ 99.90\%, Acros; zirconium oxide $\left(\mathrm{ZrO}_{2}\right)$ 99.90\%, Aldrich; chloroauric acid $\left(\mathrm{HAuCl}_{4}\right)$ 99.95\%, Acros; $\mathrm{Au}$ bromide $\left(\mathrm{AuBr}_{3}\right)$ 99.95\%, Acros; and Au iodide (AuI) 99.95\%, Acros. Both stock and reagent solutions were prepared by using deionized water.

2.2. Catalyst Preparation. The Au-catalysts were prepared in two steps: (i) preparation of the single and double oxide support and (ii) Au deposition-precipitation.

2.3. Support Preparation. Accurately weighed amounts of each oxide, $\mathrm{CeO}_{2}$ and $\mathrm{ZrO}_{2}$, and double oxide mechanical mixture of 7.5 gms $\mathrm{CeO}_{2}$ and $2.5 \mathrm{gm}^{\mathrm{ZOO}}$, were ultrasonically treated for $1 \mathrm{~h}$ in a Power Sonic 410 instrument at a high sonication frequency at room temperature. Lastly, the welltreated catalyst support was dried at $120^{\circ} \mathrm{C}$ in an oven for $2 \mathrm{~h}$ before using it for the Au deposition step.

2.4. Au Deposition on Support. The deposition-precipitation of Au on support was carried out in a Mettler Toledo Labmax reactor, which permits the precise control of the $\mathrm{pH}$, temperature, liquid reagent delivery, and mixing of the suspension. First, $13.5 \mathrm{~cm}^{3}$ of $0.1 \mathrm{M} \mathrm{KOH}$ and $3.86 \mathrm{~cm}^{3}$ of DIW per gram of the freshly prepared support were added to a Labmax reactor flask and mixed at room temperature at $180 \mathrm{rpm}$ at $\mathrm{pH}$ 12.7. The reactor temperature was raised to $60^{\circ} \mathrm{C}$ over $10 \mathrm{~min}$ before adding the precisely calculated amount of $1 \% \mathrm{Au}$ in $10 \mathrm{~cm}^{3}$ DIW using different gold precursors $\left(\mathrm{HAuCl}_{4} \cdot 3 \mathrm{H}_{2} \mathrm{O}\right.$, $\mathrm{AuBr}_{3}$ and $\mathrm{AuI}$ ) as the Au source. Very soon after the addition of $\mathrm{Au}$, the $\mathrm{pH}$ was decreased first to 10.4 and then to 8 within the next $5 \mathrm{~min}$ using consecutively $0.5 \mathrm{M}$ and $0.1 \mathrm{M} \mathrm{HNO}_{3}$. The ageing of the catalyst was carried by adding specified amounts of the Mg-citrate solution. The system was aged for $1 \mathrm{~h}$ at $60^{\circ} \mathrm{C}$ and $180 \mathrm{rpm}$.

The freshly prepared sludge was rinsed multiple times with lukewarm DIW under vacuum. The removal of chloride ions was ensured using $\mathrm{AgNO}_{3}$ test. Then the catalytic mass was dried for $4 \mathrm{~h}$ and calcined at $525^{\circ} \mathrm{C}$ for $4 \mathrm{~h}$ in air. The catalyst grains $(250-500 \mu \mathrm{m})$ were then prepared by grinding the pelletized catalytic mass. The details of the three different types of prepared catalysts are summarized in Table 1.

2.5. Catalytic Activity Test. Catalytic activity experiments for the complete oxidation of propane were carried in a PID Microactivity Reference reactor system. The reaction mixture at reactor inlet contained 0.5 vol\% propane in $\mathrm{He}$. All of the catalytic tests were carried out in a $4 \mathrm{~mm}$ diameter quartz glass reactor charged with $0.5 \mathrm{~g}$ of the catalyst at temperatures range from 30 to $450^{\circ} \mathrm{C}$ at $24000 \mathrm{~h}^{-1} \mathrm{GHSV}$. In each experiment, the temperature was increased in $15^{\circ} \mathrm{C}$ steps at a ramping rate of $10^{\circ} \mathrm{C} / \mathrm{min}$. The steady-state regime at each temperature was achieved after $45 \mathrm{~min}$.

The gas flow rates were controlled by Bronkhorst mass flow controllers with an accuracy of $0.1 \%$ of the fixed value. The temperature was kept constant within $0.5^{\circ} \mathrm{C}$ and monitored throughout the catalytic experiment using PID Microactivity Reference software.

The reaction products were periodically analysed using an intermittently connected GC. Three analyses of reaction products were recorded for each reaction condition to monitor the repeatability of the experimental measurements. In addition, all of the catalysts were used at least twice to check the reproducibility and were found to be highly reproducible (standard variance \pm 1.0 ) under the set parameters of the PID Microactivity apparatus.

Water and $\mathrm{CO}_{2}$ were the only products of the oxidation reaction at the reactor outlet in all experiments. An Agilent 7890A GC system equipped with a flame ionisation detector (FID) and thermal conductivity detector (TCD) was used to identify and monitor reaction end products. Data processing was performed using GC ChemStation B.04.03. A $0.5-\mathrm{cm}^{3}$ gas 
sample, Agilent DB1/122-1063 $(1 \mu \mathrm{m}, 60 \mathrm{~m} \times 0.25 \mathrm{~mm})$ and HayeSep Q $(2.4 \mathrm{~m})$ columns, and $\mathrm{He}$ and $\mathrm{N}_{2}$ carrier gases were used for FID and TCD, respectively.

2.6. Catalyst Characterization. Temperature programmed reduction (TPR) studies were conducted on ChemBET Pulsar TPD/TPO/TPR (Quantachrome). The well-purged sample was reduced by flow of $5 \% \mathrm{H}_{2}$ in $\mathrm{N}_{2}$ at constant flow rate of $15 \mathrm{~mL} / \mathrm{min}$ in the temperature range of $40-650^{\circ} \mathrm{C}$.

Pore volume and surface area of the support and catalysts were measured by Quantachrome Nova 2000 and Quantachrome Pore Master instrument by mercury porosimetry method. In the pore master instrument, $0.4 \mathrm{~g}$ of sample was first loaded in low-pressure station to fill the mercury into sample at $3.5 \mathrm{~atm}$. The sample cell was then loaded in highpressure station for mercury intrusion at up to $4200 \mathrm{~atm}$ and followed extrusion to ambient pressure. The results were obtained by using Quantachrome Pore Master instrument software.

X-ray Photoelectron Spectroscopy (XPS) measurements were carried out in an ultra-high vacuum multitechnique surface analysis system (SPECS GmbH, Germany) at base pressure of $10^{-10}$ bar range. A standard dual anode X-ray source SPECS XR-50 with $\mathrm{Mg}-\mathrm{K} \alpha, 1283.6 \mathrm{eV}$, was used to irradiate the sample surface with $13.5 \mathrm{kV}$ and $100 \mathrm{~W}$ and with take-off angle for electrons at $90^{\circ}$ relative to sample surface plane. As the standard practice in XPS studies, the adventitious hydrocarbon $\mathrm{C} 1 \mathrm{~s}$ line $(284.6 \mathrm{eV})$ corresponding to $\mathrm{C}-\mathrm{C}$ bond has been used as binding energy reference for the charge correction.

$\mathrm{X}$-ray powder diffraction (XRD) patterns were recorded by using INEL CPS 180 powder diffractometer EQUINOX 1000 system. Filtered Co K $\alpha 1$ radiation was used to irradiate the sample with $30 \mathrm{KV}$ and $30 \mathrm{~mA}$. Routine spectra were recorded with $2 \theta\left(10\right.$ to $\left.110^{\circ}\right)$ with a step size of $0.029^{\circ}$. The powder pattern analyses were processed by using Match $($ ) software for phase identification with both COD and ICDD databases, IMAD-INEL(C data processing software was used for graphical illustrations, and MAUD C software was used for Rietveld analysis method.

\section{Results and Discussion}

\subsection{Catalytic Activity}

3.1.1. Effect of the Support. Figure 1 provides the catalytic

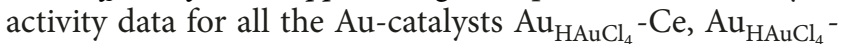
$\mathrm{Zr}$, and $\mathrm{Au}_{\mathrm{HAuCl}_{4}}{ }_{4} \mathrm{Ce}-\mathrm{Zr}$ as well as for their supports $\mathrm{CeO}_{2}$ and $\mathrm{ZrO}_{2}$ and the $\mathrm{CeO}_{2}-\mathrm{ZrO}_{2}$ mixture.

All the supports have low catalytic activity. Under the same reaction conditions, the $\mathrm{CeO}_{2}$ has shown the highest catalytic activity as compared to the other two, $\mathrm{ZrO}_{2}$ and $\mathrm{CeO}_{2}-\mathrm{ZrO}_{2}$ samples. At $400^{\circ} \mathrm{C}$, over $\mathrm{CeO}_{2}$ around $40 \%$ of the propane was oxidized. While at same reaction temperature and GHSV, over the $\mathrm{ZrO}_{2}$ propane conversion was less than $5 \%$.

The catalytic activity of the $\mathrm{CeO}_{2}-\mathrm{ZrO}_{2}$ mixture was between activities of the $\mathrm{CeO}_{2}$ and $\mathrm{ZrO}_{2}$. At $400^{\circ} \mathrm{C}$ nearly

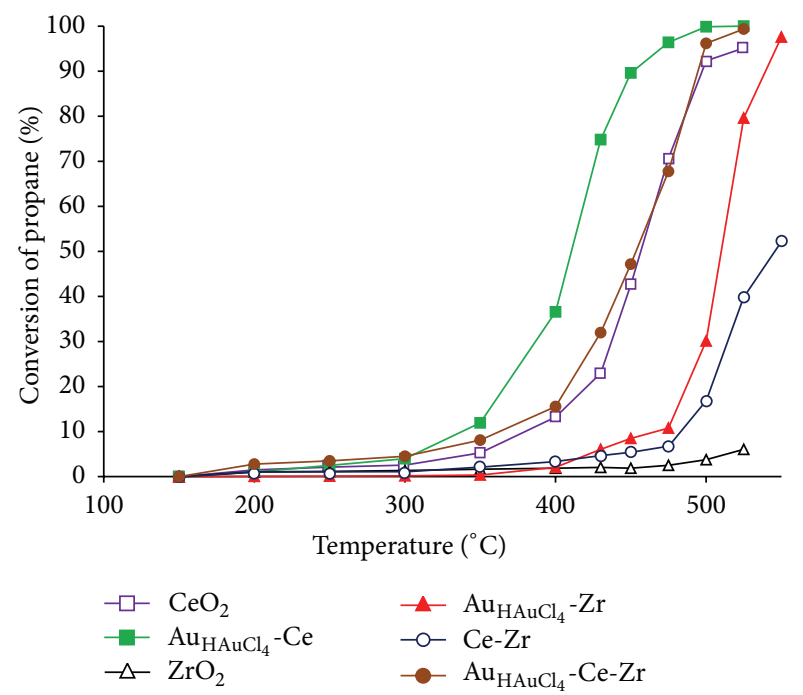

FIGURE 1: Comparison of the catalytic activity of the supports, $\mathrm{Au}_{\mathrm{HAuCl}_{4}}$-Ce catalyst, $\mathrm{Au}_{\mathrm{HAuCl}_{4}}-\mathrm{Zr}$ catalyst, and $\mathrm{Au}_{\mathrm{HAuCl}_{4}}-\mathrm{Ce}-\mathrm{Zr}$ catalyst at GHSV $24000 \mathrm{~h}^{-1}$.

$10 \%$ of the propane was oxidized. However, the mixture of both $\mathrm{ZrO}_{2}$ and $\mathrm{CeO}_{2}$ had shown increased catalytic activity at temperatures above $400^{\circ} \mathrm{C}$ in comparison to $\mathrm{ZrO}_{2}$ alone, which is because of the presence of $\mathrm{CeO}_{2}$. Therefore, $\mathrm{CeO}_{2}$, because of its high catalytic activity, is found to be the best support for preparation of $\mathrm{Au}$-catalysts for propane oxidation and it was used in our further studies.

The catalytic activities of the three Au-catalysts $\mathrm{Au}_{\mathrm{HAuCl}_{4}}$ $\mathrm{Ce}, \mathrm{Au}_{\mathrm{HAuCl}_{4}}-\mathrm{Zr}$, and $\mathrm{Au}_{\mathrm{HAuCl}_{4}}-\mathrm{Ce}-\mathrm{Zr}$ were higher than the catalytic activities of the corresponding supports. Among the Au-catalysts, the $\mathrm{Au}_{\mathrm{HAuCl}_{4}}$-Ce catalyst was found to have the highest activity for complete propane oxidation at lower temperature and $50 \%$ conversion of propane was achieved at around $410^{\circ} \mathrm{C}$. For the other two Au-catalysts $\mathrm{Au}_{\mathrm{HAuCl}_{4}}{ }^{-}$ $\mathrm{Ce}-\mathrm{Zr}$ and $\mathrm{Au}_{\mathrm{HAuCl}_{4}}-\mathrm{Zr}$, the $50 \%$ conversions were achieved at higher temperatures of $450^{\circ} \mathrm{C}$ and $510^{\circ} \mathrm{C}$, respectively. $\mathrm{Au}_{\mathrm{HAuCl}_{4}}$-Ce-Zr sample is more active than the $\mathrm{Au}_{\mathrm{HAuCl}_{4}}{ }^{-}$ $\mathrm{Zr}$, and the catalytic activity of $\mathrm{Au}_{\mathrm{HAuCl}_{4}}-\mathrm{Ce}-\mathrm{Zr}$ is higher than catalytic activity of the $\mathrm{Au}_{\mathrm{HAuCl}_{4}}-\mathrm{Zr}$. Difference between catalytic activity of $\mathrm{Au}_{\mathrm{HAuCl}_{4}}-\mathrm{Zr}$ and $\mathrm{ZrO}_{2}$ is very large as compared to the other support and respective Au-catalyst.

The results suggested that the interaction of $\mathrm{Au}$ with different catalytically active support is different. In order to investigate the effect of the Au precursor, Au-catalysts obtained from three different Au precursors on highly active support $\mathrm{CeO}_{2}$ were catalytically tested and results are discussed in next sections.

3.1.2. Effect of the Au Precursor. Figure 2 shows the catalytic activity comparison of the three Au-catalysts $\left(\mathrm{Au}_{\mathrm{HAuCl}_{4}}-\mathrm{Ce}\right.$, $\mathrm{Au}_{\mathrm{AuBr}_{3}}-\mathrm{Ce}$, and $\mathrm{Au}_{\mathrm{AuI}}-\mathrm{Ce}$ ) prepared by using three different Au precursors $\mathrm{HAuCl}_{4} \cdot 3 \mathrm{H}_{2} \mathrm{O}, \mathrm{AuBr}_{3}$, and $\mathrm{AuI}$ on the support $\mathrm{CeO}_{2}$. 
TABLE 2: Textural properties of the gold catalysts and the support.

\begin{tabular}{|c|c|c|c|c|c|}
\hline \multirow{2}{*}{ Gold catalysts } & \multirow{2}{*}{ Surface area $\left(\mathrm{m}^{2} / \mathrm{g}\right)^{\mathrm{a}}$} & \multirow{2}{*}{ Phase structure ${ }^{\mathrm{b}}$} & \multirow{2}{*}{ Particle size of gold ${ }^{c}$} & \multicolumn{2}{|c|}{ Crystal size $(\mathrm{nm})^{\mathrm{b}}$} \\
\hline & & & & $\mathrm{CeO}_{2}$ & $\mathrm{ZrO}_{2}$ \\
\hline $\mathrm{CeO}_{2}$ & 131.1 & Fluorite cubic & & 22 & \\
\hline $\mathrm{Au}_{\mathrm{HAuCl}_{4}}-\mathrm{Ce}$ & 132.0 & Fluorite cubic & $\sim 5 \mathrm{~nm}$ & 23 & \\
\hline $\mathrm{Au}_{\mathrm{AuBr}_{3}}-\mathrm{Ce}$ & 128.0 & Fluorite cubic & $\sim 14 \mathrm{~nm}$ & 24 & \\
\hline $\mathrm{Au}_{\mathrm{AuI}}-\mathrm{Ce}$ & 126.7 & Fluorite cubic & $17 \mathrm{~nm}$ & 24 & \\
\hline $\mathrm{ZrO}_{2}$ & 80.0 & Amorphous & & & 70 \\
\hline $\mathrm{Au}_{\mathrm{HAuCl}_{4}}-\mathrm{Zr}$ & 80.3 & Amorphous & - & & 72 \\
\hline $\mathrm{Ce}-\mathrm{Zr}$ & 118.0 & Fluorite cubic & & 24 & 24 \\
\hline $\mathrm{Au}_{\mathrm{HAuCl}_{4}}-\mathrm{Ce}-\mathrm{Zr}$ & 120.1 & Fluorite cubic & - & 20 & 26 \\
\hline
\end{tabular}

${ }^{\mathrm{a}}$ Obtained by $\mathrm{N}_{2}$ adsorption; ${ }^{\mathrm{b}}$ obtained by XRD; ${ }^{\mathrm{c}}$ obtained by STEM.

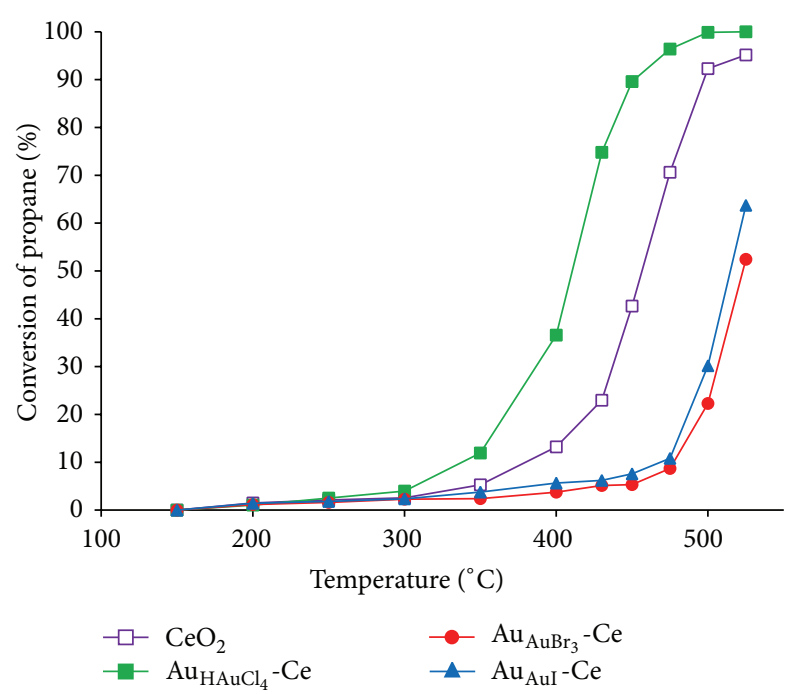

FIGURE 2: Catalytic activity comparison of the $\mathrm{Au}_{\mathrm{HAuCl}_{4}}$-Ce catalyst, $\mathrm{Au}_{\mathrm{AuBr}_{3}}$-Ce catalyst, and $\mathrm{Au}_{\mathrm{AuI}}-\mathrm{Ce}$ catalyst prepared by using three different gold precursors at GHSV $24000 \mathrm{~h}^{-1}$.

The Au-catalysts prepared from different $\mathrm{Au}$ precursor have shown different catalytic activity. The $\mathrm{Au}_{\mathrm{HAuCl}_{4}}$-Ce catalyst has the highest catalytic activity (nearly $100 \%$ conversion at $450^{\circ} \mathrm{C}$ ) in comparison to the other two catalysts $\mathrm{Au}_{\mathrm{AuBr}_{3}}-\mathrm{Ce}$ and $\mathrm{AuI} \mathrm{Au}_{\mathrm{AuI}}-\mathrm{Ce}$. The lowest catalytic activity was registered for $\mathrm{Au}_{\mathrm{AuBr}_{3}}$-Ce: $50 \%$ conversion of propane was achieved at $520^{\circ} \mathrm{C}$. Catalytic performance of the $\mathrm{Au}_{\mathrm{AuI}}$-Ce was slightly better than that of $\mathrm{Au}_{\mathrm{AuBr}_{3}}$-Ce: nearly $60 \%$ conversion of propane was obtained at $520^{\circ} \mathrm{C}$.

Interestingly, the catalytic activity order of all the Aucatalysts obtained from different $\mathrm{Au}$ precursor follows the same trends as the solubility constant $K_{\mathrm{sp}}$ of each Au precursor. The solubility constants $K_{\mathrm{sp}}$ values of the three $\mathrm{Au}$ precursors are $7.9 \times 10^{-5}$ for $\mathrm{HAuCl}_{4} \cdot 3 \mathrm{H}_{2} \mathrm{O}>1.6 \times 10^{-23}$ for $\mathrm{AuI}>4.0 \times 10^{-36}$ for $\mathrm{AuBr}_{3}$ [42]. The $K_{\text {sp }}$ value of AuI is higher than that of $\mathrm{AuBr}_{3}$ which exactly correlates with the order of activities of the catalysts prepared from AuI and $\mathrm{AuBr}_{3}$ precursors.
Based on the catalytic activity and $K_{\mathrm{sp}}$ data, the highest catalytic activity of the $\mathrm{Au}_{\mathrm{HAuCl}_{4}}$-Ce catalyst could be the result of the highest $K_{\mathrm{sp}}$ value of $\mathrm{HAuCl}_{4}$ that could have led to the better Au dispersion, an important aspect for the higher catalytic activity of the Au-catalyst.

In order to further investigate the role of different $\mathrm{Au}$ precursor to the Au-catalysts, detailed XRD, XPS, TPR, TEM, and BET analyses were also performed. The obtained results are summarized in the following sections.

3.2. Textural Property of the Au-Catalysts. It is widely accepted that high surface area is very important in enhancing the catalytic activity of the Au-catalyst $[43,44]$. As listed in Table 2, among three different supports, $\mathrm{CeO}_{2}$ has the highest surface area and the most effective support to enhance catalytic activity of Au-catalysts, whereas $\mathrm{ZrO}_{2}$ has shown least surface area and lowest catalytic activity among the supports. Surface area of $\mathrm{CeO}_{2}-\mathrm{ZrO}_{2}$ was found to be in between $\mathrm{CeO}_{2}$ and $\mathrm{ZrO}_{2}$, which is well corresponded to its catalytic activity. In summary, the observed catalytic activity of the supports is directly correlated with their surface area.

In few studies [45-47], it is reported that physical structure, crystal size, and crystalline form of the catalysts could be one of the key reasons governing the catalytic activity of Au-catalysts. As shown in Table 2, well-defined fluorite cubic structure was observed for $\mathrm{CeO}_{2}$ and $\mathrm{CeO}_{2}-\mathrm{ZrO}_{2}$ and for corresponding $\mathrm{Au}$-catalysts. In addition, smaller crystal size was observed for these catalysts $(20 \sim 25 \mathrm{~nm})$. While for $\mathrm{ZrO}_{2}$ and $\mathrm{Au}_{\mathrm{HAuCl}_{4}}-\mathrm{Zr}$ catalyst, part of the $\mathrm{ZrO}_{2}$ is amorphous and crystal size of the rest of the $\mathrm{ZrO}_{2}$ was found to be considerably large (above $70 \mathrm{~nm}$ ). This result indicates that textural properties of the supports have significant effect on enhanced catalytic activity of the Au-catalysts.

From the XRD pattern (as shown in Figure 3), it was observed that the XRD peak positions of Au-catalysts are nearly similar to the peaks of corresponding supports. The XRD peak for Au species, supposed to appear at around $38^{\circ}$ and $44^{\circ}$ [48], did not appear. This could be because of the following two reasons:

(i) The Au particles were dispersed very well on the surface of the supports and the particles size might be very small [48-50]. 
TABLE 3: The oxidation states of gold in in $\mathrm{Au}_{\mathrm{HAuCl}_{4}}$-Ce catalyst, $\mathrm{Au}_{\mathrm{AuBr}_{3}}$-Ce catalyst, $\mathrm{Au}_{\mathrm{AuI}}$-Ce catalyst, $\mathrm{Au}_{\mathrm{HAuCl}_{4}}-\mathrm{Zr}$ catalyst, and $\mathrm{Au}_{\mathrm{HAuCl}_{4}}$-Ce-Zr catalyst obtained by deconvolution of $\mathrm{Au} 4 \mathrm{f}$ peaks.

\begin{tabular}{lc}
\hline Catalyst & Gold oxidation state \\
\hline $\mathrm{Au}_{\mathrm{HAuCl}_{4}}-\mathrm{Ce}$ & $\mathrm{Au}^{+1}, \mathrm{Au}^{+3}$ \\
$\mathrm{Au}_{\mathrm{AuBr}_{3}}-\mathrm{Ce}$ & $\mathrm{Au}^{+3}, \mathrm{Au}^{-}$ \\
$\mathrm{Au}_{\mathrm{AuI}}-\mathrm{Ce}$ & $\mathrm{Au}^{+1}$ \\
$\mathrm{Au}_{\mathrm{HAuCl}_{4}}-\mathrm{Zr}$ & $\mathrm{Au}^{+1}$ \\
$\mathrm{Au}_{\mathrm{HAuCl}_{4}}-\mathrm{Ce}-\mathrm{Zr}$ & $\mathrm{Au}^{+1}, \mathrm{Au}^{+3}$ \\
\hline
\end{tabular}

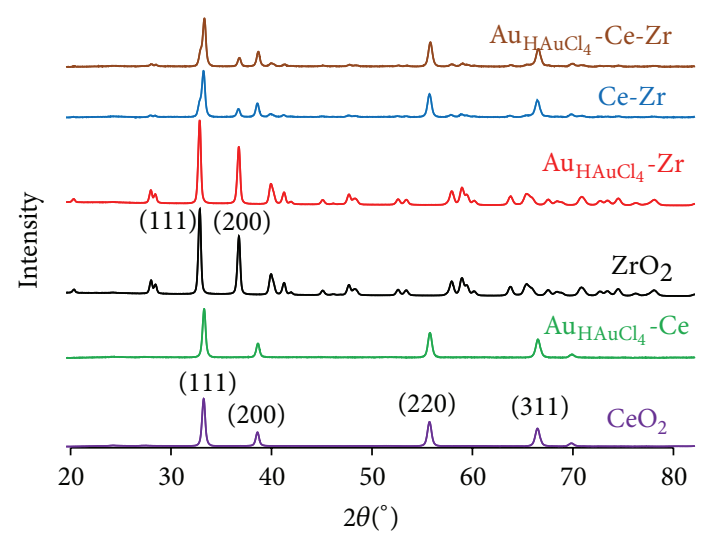

FIGURE 3: XRD pattern of the supports, $\mathrm{Au}_{\mathrm{HAuCl}_{4}}$-Ce catalyst, $\mathrm{Au}_{\mathrm{HAuCl}_{4}}-\mathrm{Zr}$ catalyst, and $\mathrm{Au}_{\mathrm{HAuCl}_{4}}-\mathrm{Ce}-\mathrm{Zr}$ catalyst at GHSV $24000 \mathrm{~h}^{-1}$.

(ii) It could be because Au loading is beyond the XRD lower sensitivity limit [49].

In summary, the presence of Au did not exhibit any influence on the crystalline planes such as of (111), (200), (220), and (311) that belong to $\mathrm{CeO}_{2}$ or the crystal structure of the respective support except a negligible change in surface area.

3.3. Influence of Oxidation State of Au. Many studies [34, $38,39,51]$ emphasized the relationship between oxidation state of $\mathrm{Au}$ and catalytic activity of Au-catalysts. Mainly, the importance of oxidized Au was discussed; however, the nature of the oxidized $\mathrm{Au}$ was not well clarified except some recent studies $[40,41]$ claiming that $\mathrm{Au}^{+1}$ is the most active $\mathrm{Au}$ oxidation during the oxidation reaction. However, our results indicated that both $\mathrm{Au}^{+1}$ and $\mathrm{Au}^{+3}$ types of the $\mathrm{Au}$ are playing very important role for the high catalytic activity of the Aucatalysts.

Figure 5 provides a comparison of the deconvoluted $\mathrm{Au} 4 \mathrm{f}$ XPS spectra of all the prepared Au-catalysts. The oxidation states of the $\mathrm{Au}$ for each of the prepared $\mathrm{Au}$ catalysts are summarized in Table 3 . From the obtained data, it can be seen that, for $\mathrm{Au}_{\mathrm{HAuCl}_{4}}$-Ce catalyst and $\mathrm{Au}_{\mathrm{HAuCl}_{4}}-\mathrm{Ce}$ $\mathrm{Zr}$ catalyst, both of $\mathrm{Au}^{+1}$ and $\mathrm{Au}^{+3}$ were present. Additionally, both of these catalysts had higher catalytic activity among the all studied $\mathrm{Au}$-catalysts. In case of $\mathrm{Au}_{\mathrm{HAuCl}_{4}}$ - $\mathrm{Zr}$ catalyst and $\mathrm{Au}_{\mathrm{AuI}}$-Ce catalyst, only $\mathrm{Au}^{+1}$ was observed, and each of these catalysts has lower catalytic activity compared to that

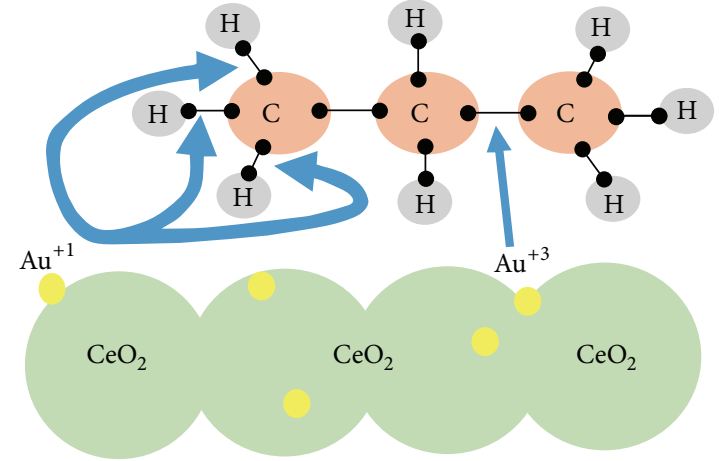

FIGURE 4: Summary of the proposed reaction mechanism for the $\mathrm{Au}_{\mathrm{HAuCl}_{4}}$-Ce catalyst.

of $\mathrm{Au}_{\mathrm{HAuCl}_{4}}$-Ce catalyst. For the $\mathrm{Au}_{\mathrm{AuBr}_{3}}$-Ce catalyst, which depicted the least catalytic activity, both $\mathrm{Au}^{+3}$ and quite high amount of negatively charged ionic $\mathrm{Au} \mathrm{Au}^{-1}$ were observed.

Results indicate that presence of both $\mathrm{Au}^{+1}$ and $\mathrm{Au}^{+3}$ plays key role in the enhanced catalytic activity of the $\mathrm{Au}_{\mathrm{HAuCl}_{4}}$-Ce catalyst as to that of $\mathrm{Au}^{+1}$ alone. The results also suggested that presence of $\mathrm{Au}^{-1}$ is not favorable for the activity of Au-catalyst. Based on the obtained results and current study, it is most probably that both $\mathrm{Au}^{+1}$ and $\mathrm{Au}^{+3}$ attack the $\mathrm{C}-\mathrm{H}$ and $\mathrm{C}-\mathrm{C}$ bond of the model compound, respectively, as the bond energy of $\mathrm{C}-\mathrm{H}(413 \mathrm{KJ} / \mathrm{mole})$ is higher as to that of $\mathrm{C}-\mathrm{C}(347 \mathrm{KJ} /$ mole $)$. Thereon initiating a disturbance in the electronic cloud vicinity of the $\mathrm{C}-\mathrm{H}$ and $\mathrm{C}-\mathrm{C}$ bond ended with the formation of unstable radicals that can easily be attacked by the free electron present on or near the surface of reduced cerium oxide as shown in Figure 4.

3.4. TPR Studies. Solsona et al. [1] suggested that redox property of the catalyst is an important factor that may influence the catalytic activity of the catalysts for propane oxidation. Obtained TPR results indicated a strong relationship between reducibility and catalytic activity of the Au-catalysts. The TPR profiles of the catalysts are presented in Figure 6.

In case of $\mathrm{CeO}_{2}$, TPR peak was obtained at $517.3^{\circ} \mathrm{C}$. Based on the literature, TPR profile of $\mathrm{CeO}_{2}$ contains two major peaks, one at lower temperature (around $500^{\circ} \mathrm{C}$ ), attributed to the reduction of oxygen on the surface, and one at higher temperature (around $800^{\circ} \mathrm{C}$ ), related to the removal of bulk oxygen from the ceria structure $[17,52,53]$. Clearly, obtained result is consistent with the results in the literature.

The TPR peak of $\mathrm{ZrO}_{2}$, attributed to the reduction of oxygen on the surface [52], catalyst was obtained at $625.2^{\circ} \mathrm{C}$. Idakiev et al. have also obtained the similar results [54].

The TPR peak of the support $\mathrm{CeO}_{2}+\mathrm{ZrO}_{2}$ was obtained at $552.8^{\circ} \mathrm{C}$. This peak represents the reduction of oxygen on the surface.

In short, the reducibility temperatures of the supports were in the order of $\mathrm{CeO}_{2}>\mathrm{CeO}_{2}+\mathrm{ZrO}_{2}>\mathrm{ZrO}_{2}$, exactly in same order as to that of the catalytic activity of these supports.

The deposition of $\mathrm{Au}$ caused a strong effect on the reducibility of catalysts. Not only oxygen species possibly 

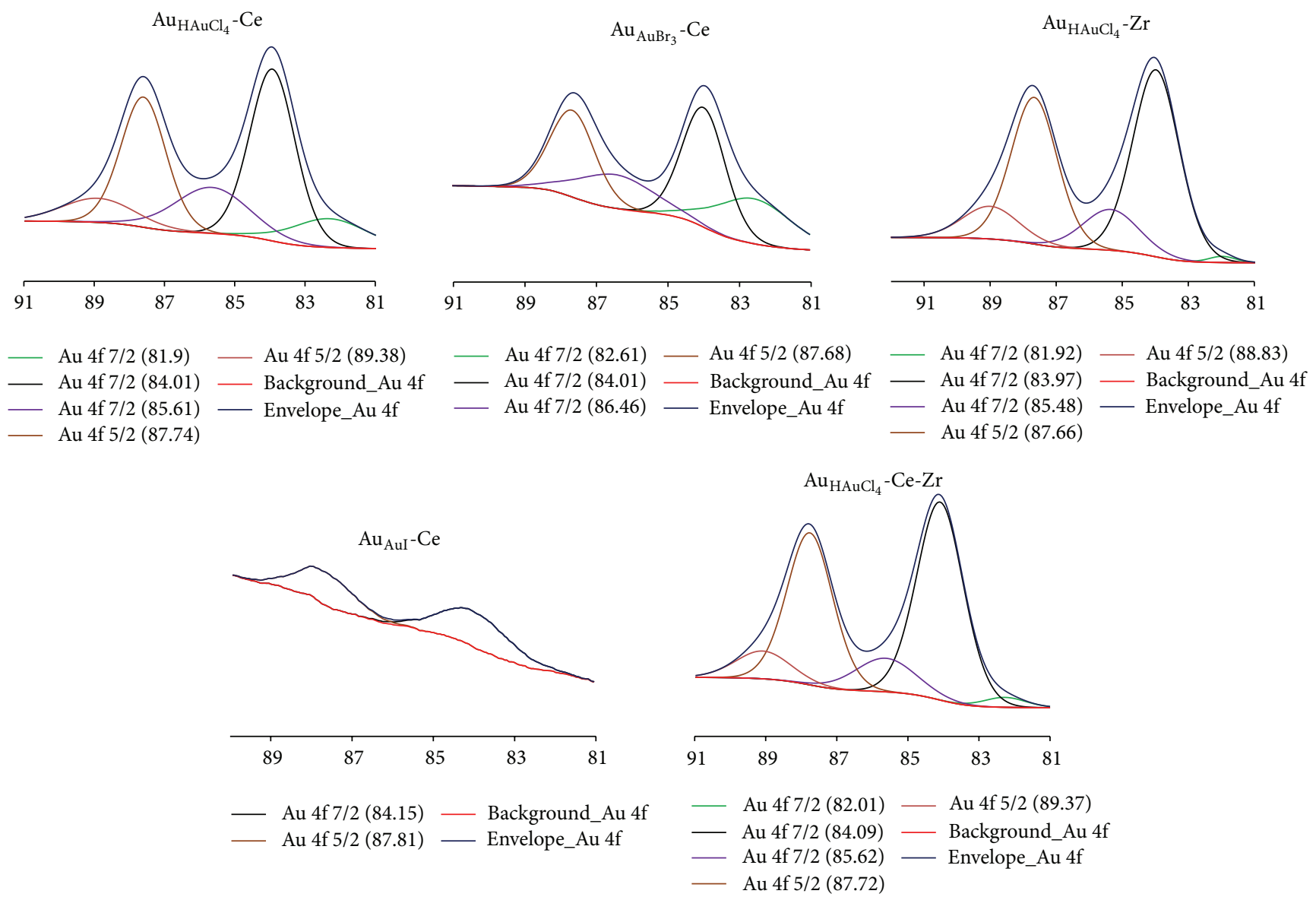

FIGURE 5: Deconvoluted XPS spectra of the $\mathrm{Au} 4 \mathrm{f}$ in $\mathrm{Au}_{\mathrm{HAuCl}_{4}}-\mathrm{Ce}$ catalyst, $\mathrm{Au}_{\mathrm{AuBr}_{3}}-\mathrm{Ce}$ catalyst, $\mathrm{Au}_{\mathrm{AuI}^{-}}-\mathrm{Ce}$ catalyst, $\mathrm{Au}_{\mathrm{HAuCl}_{4}}-\mathrm{Zr} \mathrm{catalyst}$, and $\mathrm{Au}_{\mathrm{HAuCl}_{4}}$-Ce-Zr catalyst.

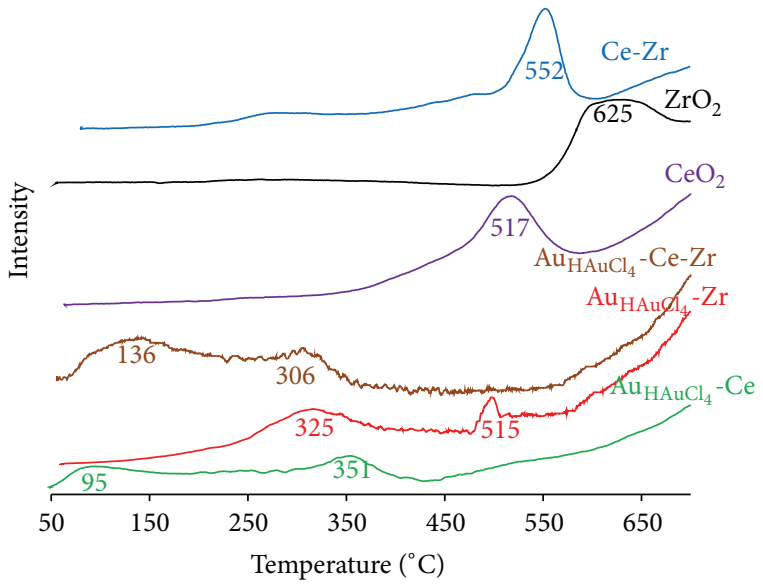

FIGURE 6: TPR study of $\mathrm{Au}_{\mathrm{HAuCl}_{4}}$-Ce catalyst, $\mathrm{Au}_{\mathrm{HAuCl}_{4}}$ - $\mathrm{Zr}$ catalyst, and $\mathrm{Au}_{\mathrm{HAuCl}_{4}}$-Ce-Zr catalyst, and corresponding supports.

adsorbed on Au nanoparticles were easily reducible, but also oxygen on the surface of catalysts was reduced at lower temperature than corresponding support. There were two TPR peaks for the $\mathrm{Au}_{\mathrm{HAuCl}_{4}}$-Ce catalyst, the first peak is at $95^{\circ} \mathrm{C}$, which attributes to the reduction of oxygen species near small Au nanoparticles, and the second peak is at $351^{\circ} \mathrm{C}$, which attributes to reduction of oxygen on the surface [52].

There were also two TPR peaks for $\mathrm{Au}_{\mathrm{HAuCl}_{4}}$ - $\mathrm{Zr}$ catalyst, but they are registered at much higher temperature of $325^{\circ} \mathrm{C}$ and $515^{\circ} \mathrm{C}$. These peaks might be attributed to the reduction of oxygen species near small Au nanoparticles and reduction of oxygen on the support surface, respectively. TPR profile for $\mathrm{Au}_{\mathrm{HAuCl}_{4}}-\mathrm{Ce}-\mathrm{Zr}$ catalyst was found to be similar to that for $\mathrm{Au}_{\mathrm{HAuCl}_{4}}$-Ce catalyst. However, compared to the $\mathrm{Au}_{\mathrm{HAuCl}_{4}}{ }^{-}$ $\mathrm{Ce}-\mathrm{Zr}$ catalyst, the temperature for the first TPR peak was lower in case of Au-Ce catalyst. Additionally broader TPR peak was obtained for $\mathrm{Au}_{\mathrm{HAuCl}_{4}}$-Ce catalyst than $\mathrm{Au}_{\mathrm{HAuCl}_{4}}{ }^{-}$ Ce- $\mathrm{Zr}$ catalyst.

The TPR result showed that redox property of the catalysts is one of the most important factors to influence catalytic activity of the catalysts for propane oxidation.

3.5. Influence of Particle Size of $A u$. Au particle size is considered to be the most critical factor, which is defining catalytic activity of gold in oxidation reactions [55-58]. It is widely accepted that the optimum Au particle size could be between 3 and $10 \mathrm{~nm}[29,58-60]$. 


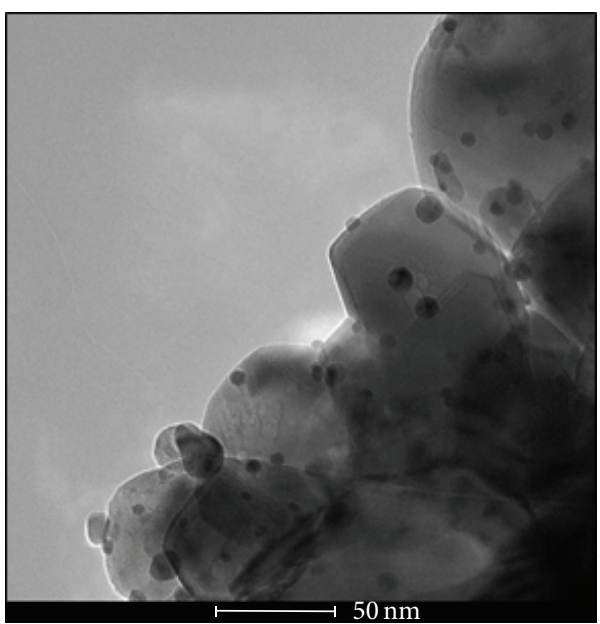

(a)

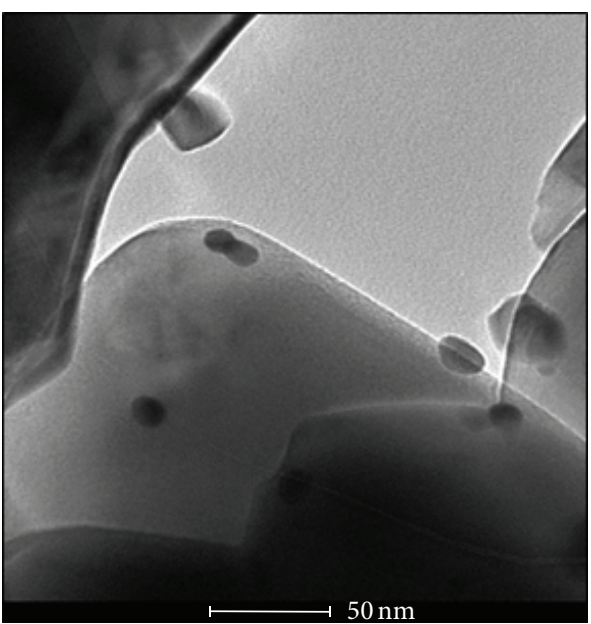

(b)

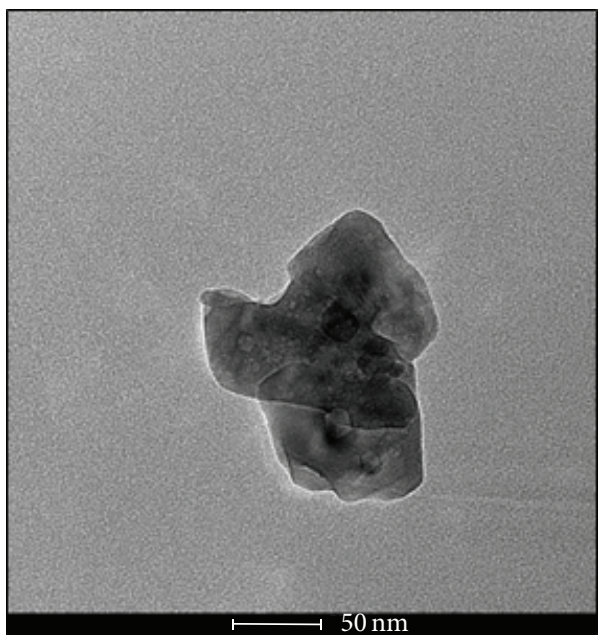

(c)

Figure 7: STEM images of $\mathrm{Au}_{\mathrm{HAuCl}_{4}}$-Ce catalyst (a), $\mathrm{Au}_{\mathrm{AuBr}_{3}}$-Ce catalyst (b), and $\mathrm{Au}_{\mathrm{AuI}^{-}}$-Ce catalyst (c).

It is well known that the fraction of surface $\mathrm{Au}$ atoms increases with the decrease in Au particle size and ultimately leads to the increased mobility of surface Au atoms. Additionally, the overlap of electron orbitals is lesser, as the average number of bonds between atoms becomes less. This leads to the band structure weakening, due to which surface atoms, in particular, start behaving as individuals rather than being in association with other atoms. This ultimately results in a greater fraction of the atoms in contact with the support [61].

Generally Au particle size depends on the nature of the support, preparation method, $\mathrm{pH}$, calcination temperature, and precipitating agent $[21-24,36,62-64]$. Interestingly, they are the same parameters affecting catalytic activity of the Aucatalysts.

In order to study the effect of different precursor to $\mathrm{Au}$ particle size, STEM measurement was carried out for the gold catalysts prepared by using three different gold precursors (as shown in Figure 7). The average Au particle size for each catalyst obtained by STEM is summarized in Table 3. The results showed that, in case of $\mathrm{Au}_{\mathrm{HAuCl}_{4}}$-Ce catalyst, $\mathrm{Au}$ particles are uniformly dispersed on the support, with an average Au particle size of around $5 \mathrm{~nm}$. However, in case of the other two catalysts $\mathrm{Au}_{\mathrm{AuBr}}-\mathrm{Ce}$ and $\mathrm{Au}_{\mathrm{AuI}}-\mathrm{Ce}, \mathrm{Au}$ has aggregated into large size of particles and average Au particle sizes for these two catalysts were found to be almost three times larger than that of $\mathrm{Au}_{\mathrm{HAuCl}_{4}}$-Ce catalyst. This could explain why these two catalysts have shown less catalytic activity as to that of $\mathrm{Au}_{\mathrm{HAuCl}_{4}}$-Ce catalyst.

\section{Conclusions}

Gold precursors strongly affect the size and dispersion of nano-Au within the Au-catalysts. Because of high dispersion and smaller size of Au particles, $\mathrm{Au}_{\mathrm{HAuCl}_{4}}$-Ce catalyst showed the highest catalytic activity for propane oxidation. Based on obtained results, the nature of both $\mathrm{Au}$ precursor and support strongly influences catalytic activity of the $\mathrm{Au}$ catalysts for the complete propane oxidation. $\mathrm{CeO}_{2}$ has shown to be the best catalytic support. It showed the highest catalytic activity in comparison to the other studied supports. 
The Au-catalyst obtained by using $\mathrm{CeO}_{2}$ as support has shown the highest catalytic activity. The $\mathrm{HAuCl}_{4} \cdot 3 \mathrm{H}_{2} \mathrm{O} \mathrm{Au}$ precursor is the most suitable and effective precursor for preparation of highly active Au-catalyst. The use of other two $\mathrm{Au}$ precursors $\mathrm{AuI}$ and/or $\mathrm{AuBr}_{3}$ leads to preparation of the catalysts of low catalytic activity. Surface properties of the catalysts exhibited that support having large surface area and small crystallites size is favorable for the preparation of highly catalytically active Au-catalyst. XPS study showed that presence of both $\mathrm{Au}^{+3}$ and $\mathrm{Au}^{+1}$ oxidation states is playing a key role for the enhanced catalytic activity of the $\mathrm{Au}-$ catalyst for the complete propane oxidation. Deposition of $\mathrm{Au}$ on the support significantly improves the redox ability of the support that ultimately leads to the enhanced catalytic activity. STEM result showed that nano-Au particle size is mandatory for high catalytic activity of the catalyst, and nature $\mathrm{Au}$ precursors strongly affect the size and dispersion of Au nanoparticles.

Nature of both $\mathrm{Au}$ precursor and support and oxidation state, surface properties, size, and dispersion of the $\mathrm{Au}$ particle are key parameters for obtaining highly active $\mathrm{Au}-$ catalysts.

\section{Conflict of Interests}

The authors declare that there is no conflict of interests regarding the publication of this paper.

\section{Acknowledgments}

The authors would like to acknowledge the King Abdulaziz University, Jeddah, for funding this project under Grant D005/431. The authors would also like to acknowledge Raouf Ahmad and Florencio Trovela for all their technical support and assistance.

\section{References}

[1] B. E. Solsona, T. Garcia, C. Jones, S. H. Taylor, A. F. Carley, and G. J. Hutchings, "Supported gold catalysts for the total oxidation of alkanes and carbon monoxide," Applied Catalysis A: General, vol. 312, no. 1-2, pp. 67-76, 2006.

[2] L. Delannoy, K. Fajerwerg, P. Lakshmanan, C. Potvin, C. Méthivier, and C. Louis, "Supported gold catalysts for the decomposition of VOC: total oxidation of propene in low concentration as model reaction," Applied Catalysis B: Environmental, vol. 94, no. 1-2, pp. 117-124, 2010.

[3] M. Lamallem, H. E. Ayadi, C. Gennequin et al., "Effect of the preparation method on $\mathrm{Au} / \mathrm{Ce}-\mathrm{Ti}-\mathrm{O}$ catalysts activity for VOCs oxidation," Catalysis Today, vol. 137, no. 2-4, pp. 367-372, 2008.

[4] M. Amann and M. Lutz, "The revision of the air quality legislation in the European Union related to ground-level ozone," Journal of Hazardous Materials, vol. 78, no. 1-3, pp. 41$62,2000$.

[5] R. Heinsohn and R. Kabel, Sources and Control of Air Pollution, Prentice Hall, 1999.

[6] A. C. Lewis, N. Carslaw, P. J. Marriott et al., "A larger pool of ozone-forming carbon compounds in urban atmospheres," Nature, vol. 405, no. 6788, pp. 778-781, 2000.
[7] R. M. Heck, R. J. Farrauto, and S. T. Gulati, Catalytic Air Pollution Control: Commercial Technology, John Wiley \& Sons, 2012.

[8] W. B. Li, W. B. Chu, M. Zhuang, and J. Hua, "Catalytic oxidation of toluene on Mn-containing mixed oxides prepared in reverse microemulsions," Catalysis Today, vol. 93-95, pp. 205-209, 2004.

[9] W. Li, J. Wang, and H. Gong, "Catalytic combustion of VOCs on non-noble metal catalysts," Catalysis Today, vol. 148, no. 1-2, pp. 81-87, 2009.

[10] T. Masui, H. Imadzu, N. Matsuyama, and N. Imanaka, “Total oxidation of toluene on $\mathrm{Pt} / \mathrm{CeO}_{2}-\mathrm{ZrO}_{2}-\mathrm{Bi}_{2} \mathrm{O}_{3} / \gamma-\mathrm{Al}_{2} \mathrm{O}_{3}$ catalysts prepared in the presence of polyvinyl pyrrolidone," Journal of Hazardous Materials, vol. 176, no. 1-3, pp. 1106-1109, 2010.

[11] T. Barakat, J. C. Rooke, M. Franco et al., "Pd- and/or Auloaded $\mathrm{Nb}$ - and V-doped macro-mesoporous $\mathrm{TiO}_{2}$ supports as catalysts for the total oxidation of VOCs," European Journal of Inorganic Chemistry, vol. 2012, no. 16, pp. 2812-2818, 2012.

[12] M. Hosseini, S. Siffert, R. Cousin, A. Aboukaïs, Z. HadjSadok, and B.-L. Su, "Total oxidation of VOCs on Pd and/or $\mathrm{Au}$ supported on $\mathrm{TiO}_{2} / \mathrm{ZrO}_{2}$ followed by "operando" DRIFT," Comptes Rendus Chimie, vol. 12, no. 6-7, pp. 654-659, 2009.

[13] M. Haruta, "Size- and support-dependency in the catalysis of gold," Catalysis Today, vol. 36, no. 1, pp. 153-166, 1997.

[14] T. Takei, I. Okuda, K. K. Bando, T. Akita, and M. Haruta, "Gold clusters supported on $\mathrm{La}(\mathrm{OH})_{3}$ for $\mathrm{CO}$ oxidation at $193 \mathrm{~K}$," Chemical Physics Letters, vol. 493, no. 4-6, pp. 207-211, 2010.

[15] M. Haruta, S. Tsubota, T. Kobayashi, H. Kageyama, M. J. Genet, and B. Delmon, "Low-temperature oxidation of $\mathrm{CO}$ over gold supported on $\mathrm{TiO}_{2}, \alpha-\mathrm{Fe}_{2} \mathrm{O}_{3}$, and $\mathrm{Co}_{3} \mathrm{O}_{4}$," Journal of Catalysis, vol. 144, no. 1, pp. 175-192, 1993.

[16] M. Haruta, H. Sano, and T. Kobayashi, "Method for manufacture of catalyst composite having gold or mixture of gold with catalytic metal oxide deposited on carrier," Google Patents, 1987.

[17] S. A. C. Carabineiro, S. S. T. Bastos, J. J. M. Órfão, M. F. R. Pereira, J. J. Delgado, and J. L. Figueiredo, "Exotemplated ceria catalysts with gold for CO oxidation," Applied Catalysis A: General, vol. 381, no. 1-2, pp. 150-160, 2010.

[18] D. Widmann, Y. Liu, F. Schüth, and R. J. Behm, "Support effects in the Au-catalyzed CO oxidation-correlation between activity, oxygen storage capacity, and support reducibility," Journal of Catalysis, vol. 276, no. 2, pp. 292-305, 2010.

[19] D. Wang, Z. Hao, D. Cheng, X. Shi, and C. Hu, "Influence of pretreatment conditions on low-temperature $\mathrm{CO}$ oxidation over $\mathrm{Au} / \mathrm{MO}_{x} / \mathrm{Al}_{2} \mathrm{O}_{3}$ catalysts," Journal of Molecular Catalysis A: Chemical, vol. 2007, no. 1-2, pp. 229-238, 2003.

[20] G. C. Bond and D. T. Thompson, "Catalysis by gold," Catalysis Reviews: Science and Engineering, vol. 41, no. 3-4, pp. 319-388, 1999.

[21] G. R. Bamwenda, S. Tsubota, T. Nakamura, and M. Haruta, "The influence of the preparation methods on the catalytic activity of platinum and gold supported on $\mathrm{TiO}_{2}$ for $\mathrm{CO}$ oxidation," Catalysis Letters, vol. 44, no. 1-2, pp. 83-87, 1997.

[22] S.-J. Lee and A. Gavriilidis, "Supported Au catalysts for lowtemperature CO oxidation prepared by impregnation," Journal of Catalysis, vol. 206, no. 2, pp. 305-313, 2002.

[23] R. Meyer, C. Lemire, S. K. Shaikhutdinov, and H.-J. Freund, "Surface chemistry of catalysis by gold," Gold Bulletin, vol. 37, no. 1-2, pp. 72-124, 2004.

[24] H. H. Kung, M. C. Kung, and C. K. Costello, "Supported $\mathrm{Au}$ catalysts for low temperature CO oxidation," Journal of Catalysis, vol. 216, no. 1-2, pp. 425-432, 2003. 
[25] F. Moreau, G. C. Bond, and A. O. Taylor, "Gold on titania catalysts for the oxidation of carbon monoxide: Control of $\mathrm{pH}$ during preparation with various gold contents," Journal of Catalysis, vol. 231, no. 1, pp. 105-114, 2005.

[26] A. Wolf and F. Schüth, "A systematic study of the synthesis conditions for the preparation of highly active gold catalysts," Applied Catalysis A: General, vol. 226, no. 1-2, pp. 1-13, 2002.

[27] G. C. Bond, C. Louis, and D. T. Thompson, Catalysis by Gold, Imperial College Press, 2006.

[28] M. A. P. Dekkers, M. J. Lippits, and B. E. Nieuwenhuys, "CO adsorption and oxidation on $\mathrm{Au} / \mathrm{TiO}_{2}$," Catalysis Letters, vol. 56, no. 4, pp. 195-197, 1998.

[29] R. Zanella, S. Giorgio, C.-H. Shin, C. R. Henry, and C. Louis, "Characterization and reactivity in $\mathrm{CO}$ oxidation of gold nanoparticles supported on $\mathrm{TiO}_{2}$ prepared by depositionprecipitation with $\mathrm{NaOH}$ and urea," Journal of Catalysis, vol. 222, no. 2, pp. 357-367, 2004.

[30] V. R. Choudhary, V. P. Patil, P. Jana, and B. S. Uphade, "Nanogold supported on $\mathrm{Fe}_{2} \mathrm{O}_{3}$ : a highly active catalyst for low temperature oxidative destruction of methane green house gas from exhaust/waste gases," Applied Catalysis A: General, vol. 350, no. 2, pp. 186-190, 2008.

[31] F. Boccuzzi, A. Chiorino, M. Manzoli et al., " $\mathrm{Au} / \mathrm{TiO}_{2}$ nanosized samples: a catalytic, TEM, and FTIR study of the effect of calcination temperature on the CO oxidation," Journal of Catalysis, vol. 202, no. 2, pp. 256-267, 2001.

[32] M. Daté, Y. Ichihashi, T. Yamashita, A. Chiorino, F. Boccuzzi, and M. Haruta, "Performance of $\mathrm{Au} / \mathrm{TiO}_{2}$ catalyst under ambient conditions," Catalysis Today, vol. 72, no. 1-2, pp. 89-94, 2002.

[33] V. I. Sobolev and L. V. Pirutko, "Room temperature reduction of $\mathrm{N}_{2} \mathrm{O}$ by $\mathrm{CO}$ over $\mathrm{Au} / \mathrm{TiO}_{2}$," Catalysis Communications, vol. 18, pp. 147-150, 2012.

[34] V. R. Choudhary, D. K. Dumbre, N. S. Patil, B. S. Uphade, and S. K. Bhargava, "Epoxidation of styrene by t-butyl hydroperoxide over gold nanoparticles supported on $\mathrm{Yb}_{2} \mathrm{O}_{3}$ : effect of gold deposition method, gold loading, and calcination temperature of the catalyst on its surface properties and catalytic performance," Journal of Catalysis, vol. 300, pp. 217-224, 2013.

[35] M. Olea, M. Tada, and Y. Iwasawa, "TAP study on carbon monoxide oxidation over supported gold catalysts $\mathrm{Au} / \mathrm{Ti}(\mathrm{OH})_{4}^{*}$ and $\mathrm{Au} / \mathrm{Fe}(\mathrm{OH})_{3}^{*}$ : moisture effect," Journal of Catalysis, vol. 248, no. 1, pp. 60-67, 2007.

[36] H. S. Oh, J. Yang, C. Costello et al., "Selective catalytic oxidation of CO: effect of chloride on supported Au catalysts," Journal of Catalysis, vol. 210, no. 2, pp. 375-386, 2002.

[37] S. A. Kondrat, G. Shaw, S. J. Freakley et al., "Physical mixing of metal acetates: a simple, scalable method to produce active chloride free bimetallic catalysts," Chemical Science, vol. 3, no. 10, pp. 2965-2971, 2012.

[38] K. M. Parida, N. Sahu, P. Mohapatra, and M. S. Scurrell, "Low temperature $\mathrm{CO}$ oxidation over gold supported mesoporous $\mathrm{Fe}$ $\mathrm{TiO}_{2}$," Journal of Molecular Catalysis A: Chemical, vol. 319, no. 1-2, pp. 92-97, 2010.

[39] H. Wang, H. Zhu, Z. Qin, F. Liang, G. Wang, and J. Wang, "Deactivation of a $\mathrm{Au} / \mathrm{CeO}_{2}-\mathrm{Co}_{3} \mathrm{O}_{4}$ catalyst during $\mathrm{CO}$ preferential oxidation in $\mathrm{H}_{2}$-rich stream," Journal of Catalysis, vol. 264, no. 2, pp. 154-162, 2009.

[40] E. Smolentseva, A. Simakov, S. Beloshapkin et al., "Gold catalysts supported on nanostructured $\mathrm{Ce}-\mathrm{Al}-\mathrm{O}$ mixed oxides prepared by organic sol-gel," Applied Catalysis B: Environmental, vol. 115-116, pp. 117-128, 2012.
[41] M. Sanchez-Dominguez, L. F. Liotta, G. Di Carlo et al., "Synthesis of $\mathrm{CeO}_{2}, \mathrm{ZrO}_{2}, \mathrm{Ce}_{0.5} \mathrm{Zr}_{0.5} \mathrm{O}_{2}$, and $\mathrm{TiO}_{2}$ nanoparticles by a novel oil-in-water microemulsion reaction method and their use as catalyst support for CO oxidation," Catalysis Today, vol. 158, no. 1-2, pp. 35-43, 2010.

[42] J. Moore, C. Stanitski, and P. Jurs, Principles of Chemistry: The Molecular Science, Cengage Learning, Boston, Mass, USA, 2009.

[43] A. C. Gluhoi, N. Bogdanchikova, and B. E. Nieuwenhuys, "The effect of different types of additives on the catalytic activity of $\mathrm{Au} / \mathrm{Al}_{2} \mathrm{O}_{3}$ in propene total oxidation: transition metal oxides and ceria," Journal of Catalysis, vol. 229, no. 1, pp. 154-162, 2005.

[44] B. Solsona, T. Garcia, E. Aylón et al., "Promoting the activity and selectivity of high surface area $\mathrm{Ni}-\mathrm{Ce}-\mathrm{O}$ mixed oxides by gold deposition for VOC catalytic combustion," Chemical Engineering Journal, vol. 175, no. 1, pp. 271-278, 2011.

[45] S. Carrettin, P. Concepción, A. Corma, J. M. López Nieto, and V. F. Puntes, "Nanocrystalline $\mathrm{CeO}_{2}$ increases the activity of Au for CO oxidation by two orders of magnitude," Angewandte Chemie-International Edition, vol. 43, no. 19, pp. 2538-2540, 2004.

[46] H. Liu, A. I. Kozlov, A. P. Kozlova, T. Shido, K. Asakura, and Y. Iwasawa, "Active oxygen species and mechanism for low-temperature $\mathrm{CO}$ oxidation reaction on $\mathrm{TiO}_{2}$-supported $\mathrm{Au}$ catalyst prepared from $\mathrm{Au}\left(\mathrm{PPh}_{3}\right)\left(\mathrm{NO}_{3}\right)$ and as-precipitated titanium hydroxide," Journal of Catalysis, vol. 185, no. 2, pp. 252 264, 1999.

[47] X. Zhang, H. Wang, and B.-Q. Xu, "Remarkable nanosize effect of zirconia in $\mathrm{Au} / \mathrm{ZrO}_{2}$ catalyst for $\mathrm{CO}$ oxidation," The Journal of Physical Chemistry B, vol. 109, no. 19, pp. 9678-9683, 2005.

[48] M. Ousmane, L. F. Liotta, G. D. Carlo et al., "Supported $\mathrm{Au}$ catalysts for low-temperature abatement of propene and toluene, as model VOCs: support effect," Applied Catalysis B: Environmental, vol. 101, no. 3-4, pp. 629-637, 2011.

[49] T. Sakwarathorn, A. Luengnaruemitchai, and S. Pongstabodee, "Preferential $\mathrm{CO}$ oxidation in $\mathrm{H}_{2}$-rich stream over $\mathrm{Au} / \mathrm{CeO}_{2}$ catalysts prepared via modified deposition-precipitation," Journal of Industrial and Engineering Chemistry, vol. 17, no. 4, pp. 747-754, 2011.

[50] X. Zhang, H. Shi, and B.-Q. Xu, "Comparative study of $\mathrm{Au} / \mathrm{ZrO}_{2}$ catalysts in $\mathrm{CO}$ oxidation and 1,3-butadiene hydrogenation," Catalysis Today, vol. 122, no. 3-4, pp. 330-337, 2007.

[51] A. M. Ali, M. A. Daous, A. A. M. Khamis, H. Driss, R. Burch, and L. A. Petrov, "Strong synergism between gold and manganese in an $\mathrm{Au}-\mathrm{Mn}$ /triple-oxide-support (TOS) oxidation catalyst," Applied Catalysis A: General, vol. 489, pp. 24-31, 2014.

[52] T. Tabakova, G. Avgouropoulos, J. Papavasiliou et al., "COfree hydrogen production over $\mathrm{Au} / \mathrm{CeO}_{2}-\mathrm{Fe}_{2} \mathrm{O}_{3}$ catalysts: part 1. Impact of the support composition on the performance for the preferential CO oxidation reaction," Applied Catalysis B: Environmental, vol. 101, no. 3-4, pp. 256-265, 2011.

[53] O. H. Laguna, F. Romero Sarria, M. A. Centeno, and J. A. Odriozola, "Gold supported on metal-doped ceria catalysts $(\mathrm{M}=$ $\mathrm{Zr}, \mathrm{Zn}$ and $\mathrm{Fe}$ ) for the preferential oxidation of CO (PROX)," Journal of Catalysis, vol. 276, no. 2, pp. 360-370, 2010.

[54] V. Idakiev, L. Ilieva, D. Andreeva, J. L. Blin, L. Gigot, and B. L. Su, "Complete benzene oxidation over gold-vanadia catalysts supported on nanostructured mesoporous titania and zirconia," Applied Catalysis A: General, vol. 243, no. 1, pp. 25-39, 2003.

[55] Y. Zhu, S. Chen, X. Lu, Z. Yang, X. Feng, and H. Wang, "Oxidation of carbon monoxide over a fibrous titania-supported gold catalyst," Chinese Journal of Catalysis, vol. 30, no. 5, pp. 421-425, 2009. 
[56] T. A. Zepeda, A. Martinez-Hernández, R. Guil-López, and B. Pawelec, "Preferential CO oxidation in excess of hydrogen over $\mathrm{Au} / \mathrm{HMS}$ catalysts modified by $\mathrm{Ce}, \mathrm{Fe}$ and Ti oxides," Applied Catalysis B: Environmental, vol. 100, no. 3-4, pp. 450-462, 2010.

[57] S. Ivanova, V. Pitchon, Y. Zimmermann, and C. Petit, "Preparation of alumina supported gold catalysts: influence of washing procedures, mechanism of particles size growth," Applied Catalysis A: General, vol. 298, no. 1-2, pp. 57-64, 2006.

[58] K. Morgan, R. Burch, M. Daous et al., "Application of halohydrocarbons for the re-dispersion of gold particles," Catalysis Science and Technology, vol. 4, no. 3, pp. 729-737, 2014.

[59] R. Grisel, K.-J. Weststrate, A. Gluhoi, and B. E. Nieuwenhuys, "Catalysis by gold nanoparticles," Gold Bulletin, vol. 35, no. 2, pp. 39-45, 2002.

[60] M. Valden, X. Lai, and D. W. Goodman, "Onset of catalytic activity of gold clusters on titania with the appearance of nonmetallic properties," Science, vol. 281, no. 5383, pp. 16471650, 1998.

[61] G. C. Bond, "Gold: a relatively new catalyst," Catalysis Today, vol. 72, no. 1-2, pp. 5-9, 2002.

[62] S. Tsubota, T. Nakamura, K. Tanaka, and M. Haruta, "Effect of calcination temperature on the catalytic activity of Au colloids mechanically mixed with $\mathrm{TiO}_{2}$ powder for CO oxidation," Catalysis Letters, vol. 56, no. 3-4, pp. 131-135, 1998.

[63] M. Á. Centeno, I. Carrizosa, and J. A. Odriozola, "Depositionprecipitation method to obtain supported gold catalysts: Dependence of the acid-base properties of the support exemplified in the system $\mathrm{TiO}_{2}$-TiOxNy-TiN," Applied Catalysis A: General, vol. 246, no. 2, pp. 365-372, 2003.

[64] M. A. Centeno, K. Hadjiivanov, T. Venkov, H. Klimev, and J. A. Odriozola, "Comparative study of $\mathrm{Au} / \mathrm{Al}_{2} \mathrm{O}_{3}$ and $\mathrm{Au} / \mathrm{CeO}_{2}-$ $\mathrm{Al}_{2} \mathrm{O}_{3}$ catalysts," Journal of Molecular Catalysis A: Chemical, vol. 252, no. 1-2, pp. 142-149, 2006. 

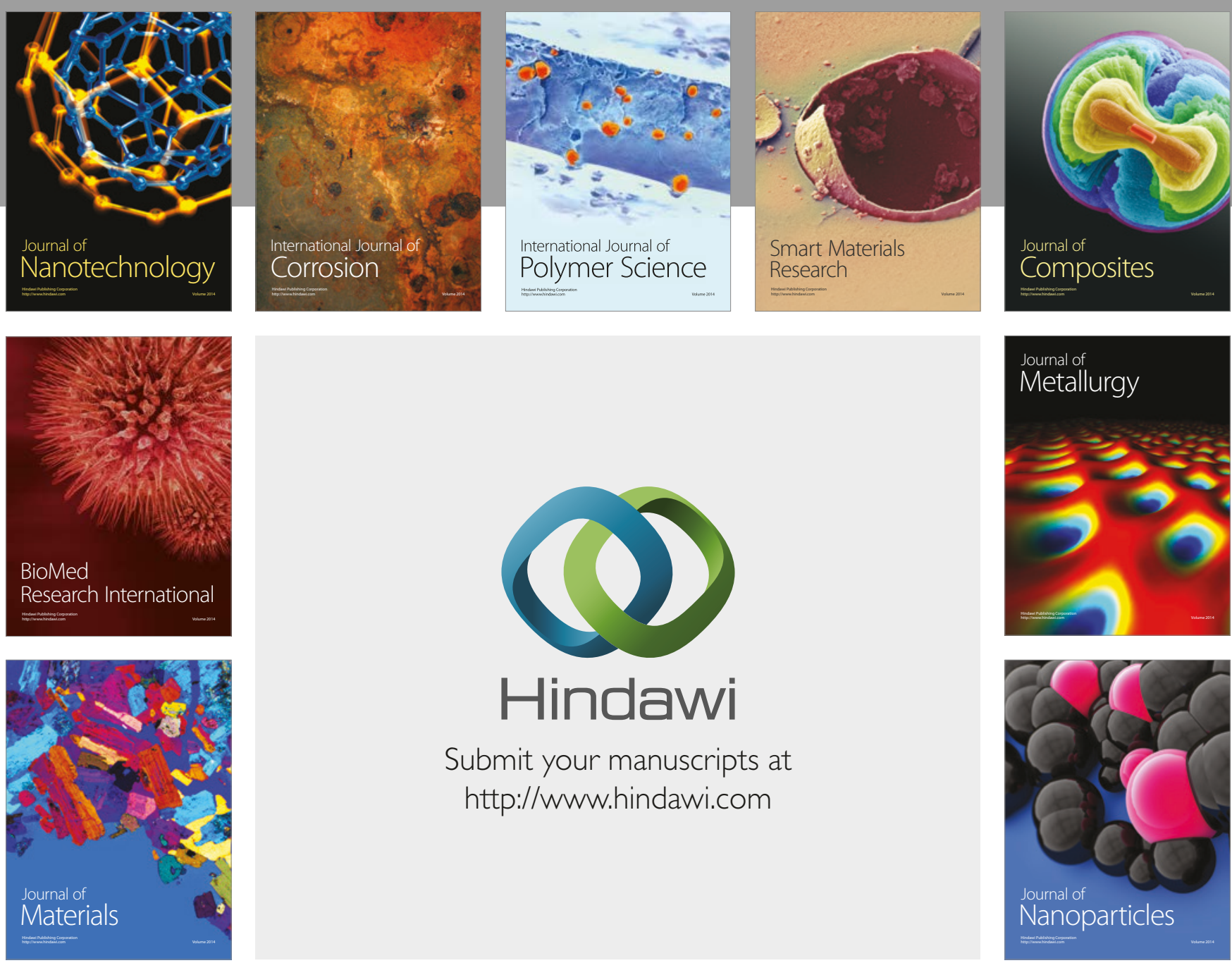

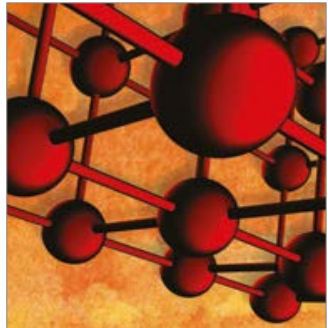

Materials Science and Engineering
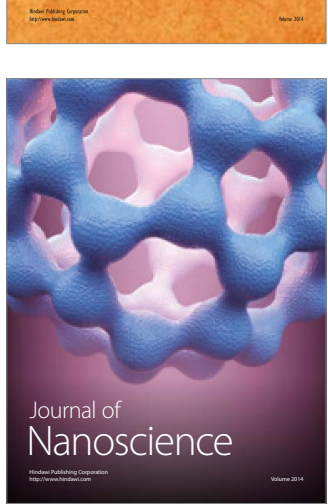

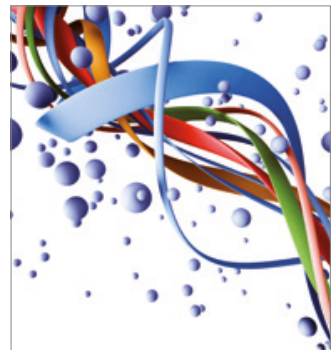

Scientifica

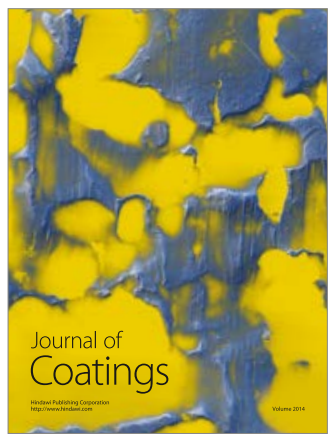

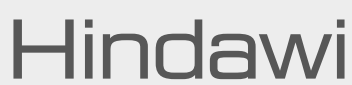

Submit your manuscripts at http://www.hindawi.com
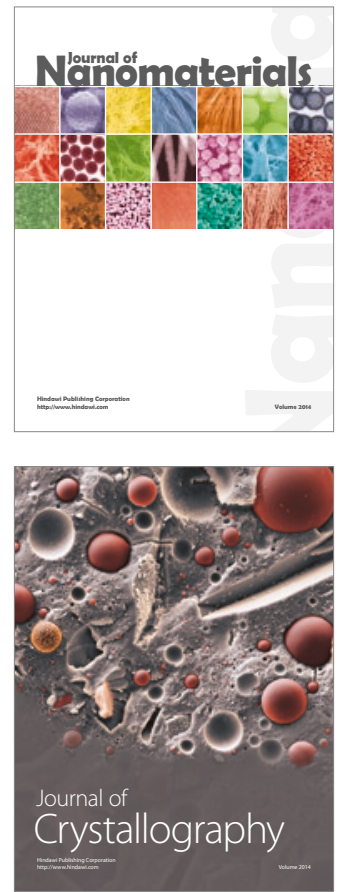

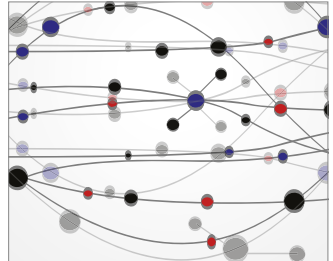

The Scientific World Journal

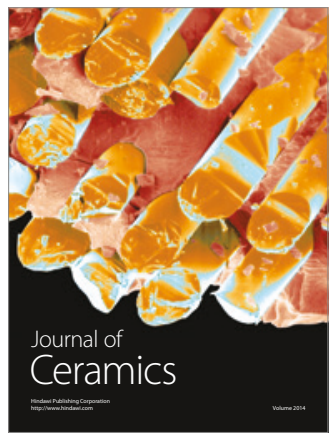

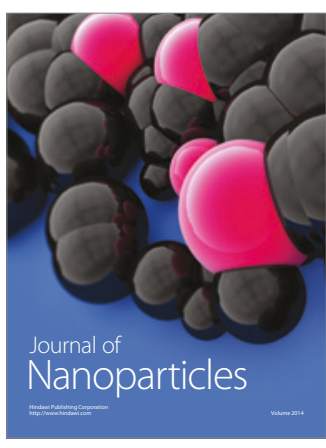
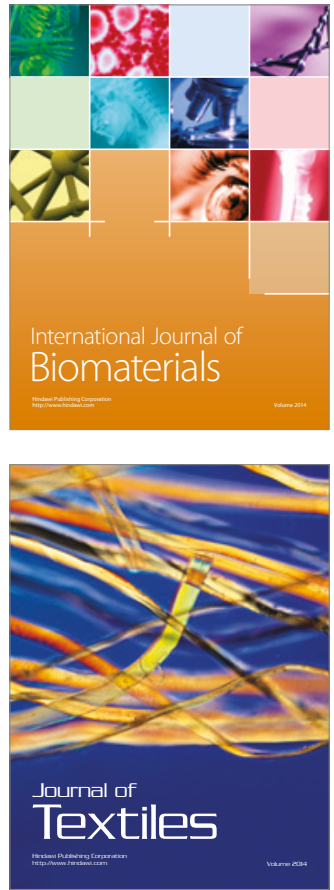